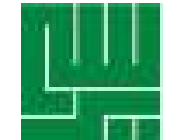

\title{
Laporan Kasus TB paru koinfeksi HIV/AIDS
}

\section{Case Report of Pulmonary TB with HIV/AIDS Coinfection}

\author{
Ibnu Arief Dafitri, Irvan Medison, Dessy \\ Mizaris. \\ Departemen Pulmonologi dan Kedokteran Respirasi, Fakultas \\ Kedokteran Universitas Andalas/RSUP DR. M. Djamil \\ Padang, Indonesia
}

\author{
KATA KUNCI \\ Tuberkulosis, HIV/AIDS, koinfeksi \\ KEYWORDS \\ Tuberculosis, HIV/AIDS, coinfection
}

ABSTRAK

TB paru merupakan penyakit infeksi yang sering dijumpai di Indonesia. TB paru masih menjadi permasalahan kesehatan di dunia, dengan harapan di tahun 2030 kasus TB paru dapat dieradikasi secara tuntas. Bersamaan dengan kasus TB paru yang belum tuntas, infeksi HIV/AIDS masih cukup tinggi di negara-negara berkembang termasuk Indonesia. Infeksi HIV/AIDS dapat memperberat kondisi klinis pasien TB paru itu sendiri. Mendiagnosis kasus TB paru pada pasien dengan HIV/AIDS pada prinsipnya tidak berbeda dengan kasus TB paru tampa konfeksi HIV/AIDS. Pemeriksaan standar pada kasus TB paru berdasarkan pemeriksaan mikrobiologi berupa pemeriksaan sputum BTA dan tes cepat molekular untuk mengetahui adanya kuman yang telah resisten terhadap obat rifampisin. Pemeriksaan radiologi tetap diperlukan untuk membantu diagnosis TB paru, terutama pada pasien-pasien yang sukar mengeluarkan sputumnya. Pemeriksaan radiologi juga bermanfaat untuk melihat luasnya lesi paru yang diakibatkan oleh kuman Mycobacterium tuberculosis dan penyakit oportunistik lain yang menyerang paru penderita dengan konfeksi HIV/AIDS. Pemberian obat Anti Retro Viral (ARV) pada kasus ini sebaiknya dimulai dalam waktu 2 minggu setelah pemberian Obat Anti Tuberkulosis (OAT).

ABSTRACT Pulmonary TB is an infectious disease that occurring frequently in Indonesia. It is still being a health problem in the world, with expectation in 2030 it will be eradicated completely. Along with unresolved pulmonary TB cases, HIV/AIDS infection is still quite high in developing countries including in Indonesia. HIV/AIDS infection able to deteriorate clinical condition of pulmonary TB patients themselves. There is no difference in 
diagnosis pulmonary TB patients with/without HIV/AIDS coinfection. Standard examination of pulmonary TB based on microbiological examination such as sputum smear for acid fast bacilli and rapid molecular tests to detect the presence of germs that have been resistant to rifampicin drugs. Radiological examination is still being required to assist pulmonary TB diagnosis, especially in patients who have difficulty in expelling sputum. Radiological examination is also useful to witness lung lesion extension caused by the bacteria Mycobacterium tuberculosis and other opportunistic lung diseases that attack the lungs of patients with HIV/AIDS coinfection. Anti Retroviral ( $A R V)$ therapy in this case should be initiated within 2 weeks after the onset of Anti Tuberculosis treatment.

\section{PENDAHULUAN}

Tuberkulosis (TB) merupakan permasalahan kesehatan yang masih menjadi perhatian dunia saat ini. Salah satu target yang ingin dicapai dalam pelaksanaan Sustainable Development Goals (SDGs) 2030 adalah mengakhiri epidemi TB secara global (WHO, 2016) Sejak tahun 1993 World Health Organization (WHO) telah mencanangkan TB sebagai kedaruratan dunia (global emergency) (Kemkes RI, 2014). Jumlah kasus baru TB di Indonesia sebanyak 420.994 kasus pada tahun 2017. Berdasarkan jenis kelamin, jumlah kasus baru TB tahun 2017 pada laki-laki 1,4 kali lebih besar dibandingkan pada perempuan. Hal ini terjadi kemungkinan karena laki-laki lebih terpapar faktor risiko TB misalnya merokok dan ketidakpatuhan dalam minum obat. Hasil survei menemukan bahwa dari seluruh partisipan laki-laki yang merokok sebanyak 68,5\% dan hanya 3,7\% partisipan perempuan yang merokok (Kemkes RI, 2018). Berbagai upaya pengendalian telah dilakukan untuk menurunkan insiden dan kematian akibat TB. Strategi DOTS (Directly Observed Treatment Short-course) telah diterapkan oleh banyak negara sejak tahun 1995 (WHO, 2015). Meskipun strategi tersebut terbukti cukup efektif dalam pengendalian TB, namun beban penyakit $\mathrm{TB}$ di masyarakat masih cukup besar (Budi dkk, 2018). HIV (Human Immunodeficiency Virus)/AIDS (Acquired Immuno-deficiency Syndrome) merupakan permasalahan kesehatan lainnya yang juga mengancam Indonesia dan seluruh negara di dunia. Seiring dengan perkembangan epidemi HIV/AIDS diperkirakan jumlah penderita HIV/AIDS juga meningkat. Di Indonesia, estimasi jumlah orang dengan HIV / AIDS (ODHA) pada tahun 2015 sebanyak 735.256 orang. Infeksi HIV/ AIDS ini dapat ditularkan melalui hubungan seksual yang tidak aman, penggunaan Napza suntik (penasun), produk darah, maupun penularan dari ibu ke anak (perinatal) (Kemkes RI, 2014). Koinfeksi TB dan HIV merupakan kombinasi penyakit yang mematikan.

\footnotetext{
Correspondence:

Ibnu Arief Dafitri, Departemen Pulmonologi dan Kedokteran Respirasi, Fakultas Kedokteran Universitas Andalas

Email:ibnu.arief@gmail.com
} 
Seseorang yang terinfeksi HIV akan menderita infeksi oportunistik (IO) selama perjalanan alamiah penyakit. TB adalah salah satu infeksi oportunistik yang sering ditemukan pada kasus infeksi HIV dan mungkin mendahului terjadinya perkembangan AIDS, tapi seringnya keduanya terdiagnosis secara bersamaan. Di seluruh dunia terdapat 350.000 kematian akibat HIV dengan TB pada tahun 2000. Hal ini dapat disebabkan oleh keterlambatan diagnosis dan pengobatan TB (Kemkes RI, 2005). WHO memperkirakan jumlah pasien TB dengan status HIV positif di Indonesia pada tahun 2013 sebesar 7,5\%, terjadi peningkatan jika dibandingkan tahun 2012 yang hanya 3,3\%. Survei prevalensi HIV diantara pasien TB baru di beberapa provinsi menunjukkan hasil dari 2\% di Yogyakarta (2006), 0,8\% di Jawa Timur, 3,8\% di Bali dan 14\% di Papua. Epidemi HIV menunjukkan pengaruh terhadap peningkatan epidemi TB di seluruh dunia yang berakibat meningkatnya jumlah kasus TB di masyarakat. Pandemi HIV merupakan tantangan terbesar dalam pengendalian TB. Di Indonesia diperkirakan sekitar 3\% pasien TB dengan status HIV positif. Sebaliknya TB merupakan tantangan bagi pengendalian HIV/AIDS karena merupakan infeksi oportunistik terbanyak (49\%) pada ODHA (Kemkes RI, 2012).

\section{KASUS}

Telah dirawat pasien laki-laki usia 43 tahun dengan diagnosis TB paru terkonfirmasi bakteriologi dalam pengobatan OAT kategori I fase intensif dan SIDA. Diagnosis ditegakkan dari hasil anamnesa, pemeriksaan fisik, dan pemeriksaan penunjang. Pasien ini juga terdiagnosis sebagai Sindrom Imuno-
Defisiensi Akuista,dengan faktor risiko seks yang tidak sehat. Pasien sudah pernah mendapatkan OAT kategori I selama seminggu namun dihentikan sendiri oleh pasien dikarenakan ingin berobat alternatif. Pada kunjungan berikutnya ke spesialis paru, pasien mendapatkan OAT kategori I berdfasarkan hasil pemeriksaan BTA sputum. Pasien dirawat di RS Ibnu Sina Padang selama 5 hari, kemudian dikirim ke RSUP M.Djamil untuk penelusuran dan tatalaksana SIDAnya. Pemeriksaan rapid test untuk mendiagnosis SIDA di RSUP dr. M. Djamil Padang menunjukkan kepositifan. Pemeriksaan TCM sputum pada pasien ini menunjukkan kuman MTB terdeteksi medium namun tidak terdeteksi kuman yang resisten terhadap rifampisin.

Pemberian OAT kategori I tetap dilanjutkan pada pasien ini dengan mempertimbangkan gejala klinis pasien, pemeriksaan fisik, pemeriksaan bakteriologis berupa TCM, dan radiologis. OAT kategori I fase intensif tersebut melanjutkan regimen obat yang telah diberikan oleh Dokter Spesialis Paru RS Ibnu Sina Padang sebelumnya. Selain menderita TB paru yang dibuktikan oleh pemeriksaan klinis, pemeriksaan rontgen toraks, dan mikrobiologi, pasien juga terdiagnosis sebagai penderita AIDS yang dibuktikan dengan hasil rapid test yang positif. Selama rawatan di bangsal paru, pasien menunjukkan perbaikan gejala klinis. Keluhan klinis yang timbul selama minum OAT kategori I fase intensif berupa gejala mual dan rasa perih di bagian ulu hati. Keluhan ini dapat ditatalaksana dengan baik dengan pemberian edukasi cara minum obat OAT dan pemberian obat untuk mengurangi dyspepsia seperti lansoprazole dan sukralfat sirup. 


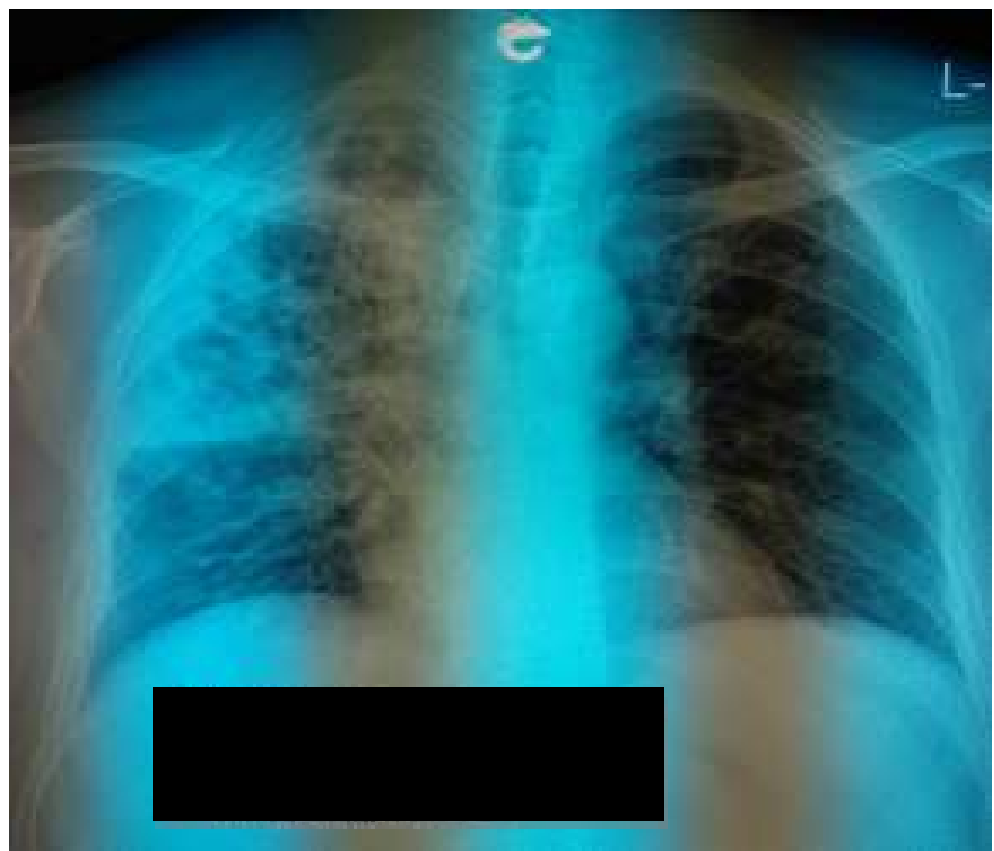

Gambar 1. Foto toraks di RSU Ibnu Sina Padang

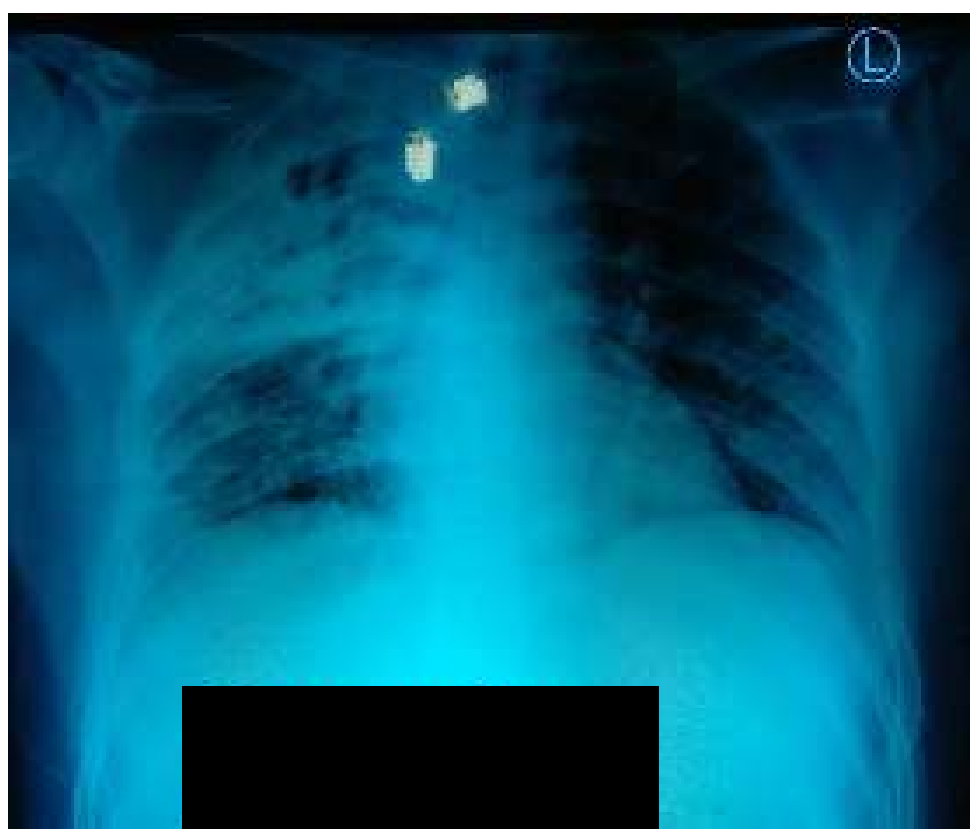

Gambar 2. Foto toraks di RSUP dr. M. Djamil Padang

PEMBAHASAN

Pemeriksaan rontgen torak dilakukan pada pasien TB paru yang tidak dapat dilakukan pemeriksaan dahak walaupun sudah dilakukan induksi sputum. Namun tidak dibenarkan menegakkan diagnostik hanya berdasarkan pemeriksaan rontgen semata. Pada pemeriksaan rontgen torak pada pasien $\mathrm{TB}$ tanpa AIDS seringkali menunjukkan infiltrat pada apeks paru. Namun pada pasien ODHA, terutama pada stadium lanjut, seringkali menunjukkan infiltrate TB Paru adalah penyakit infeksi yang disebabkan oleh Mycobacterium tuberculosis dengan gejala seperti batuk lebih dari 2 minggu, batuk berdarah, sesak nafas, nyeri dada, dan demam 
yang bersifat hilang timbul. Gejala tersebut bervariasi diantara pasien, dari mulai tidak ada gejala yang khas sampai menimbulkan gejala yang cukup berat tergantung luas lesi paru (FK UNS, 2017).

Koinfeksi TB sering terjadi pada pasien ODHA. Orang dengan HIV mempunyai kemungkinan sekitar 30 kali berisiko untuk sakit TB dibandingkan dengan orang yang tidak terinfeksi HIV. Lebih dari 25\% kematian pada pasien ODHA disebabkan oleh TB. Sekitar 320.000 orang meninggal karena HIV terkait dengan TB. Tuberkulosis merupakan infeksi oportunistik yang sering dijumpai pada ODHA selain kandidiasis, PCP, toksoplasmosis, kriptospiroidosis. Seseorang dengan koinfeksi TB/HIV memiliki masalah kesehatan yang serius dan dapat menyebabfkan kematian. Oleh karena itu penatalaksanaan yang cepat dan tepat sangat diperlukan (Kemkes RI, 2015).

Penegakkan diagnosis TB paru pada ODHA pada prinsipnya sama dengan orang HIV negatif. Diagnosis harus ditegakkan terlebih dahulu dengan konfirmasi bakteriologis, yaitu pemeriksaan mikrobiologis langsung, tes cepat, atau biakan. Apabila hasil pemeriksaan secara bakteriologis hasilnya negatif, maka penegakkan diagnostik TB dapat dilakukan dilakukan secara klinis menggunakan hasil pemeriksaan penunjang, seperti hasil pemeriksaan rontgen torak yang sesuai (FK UNS, 2017).

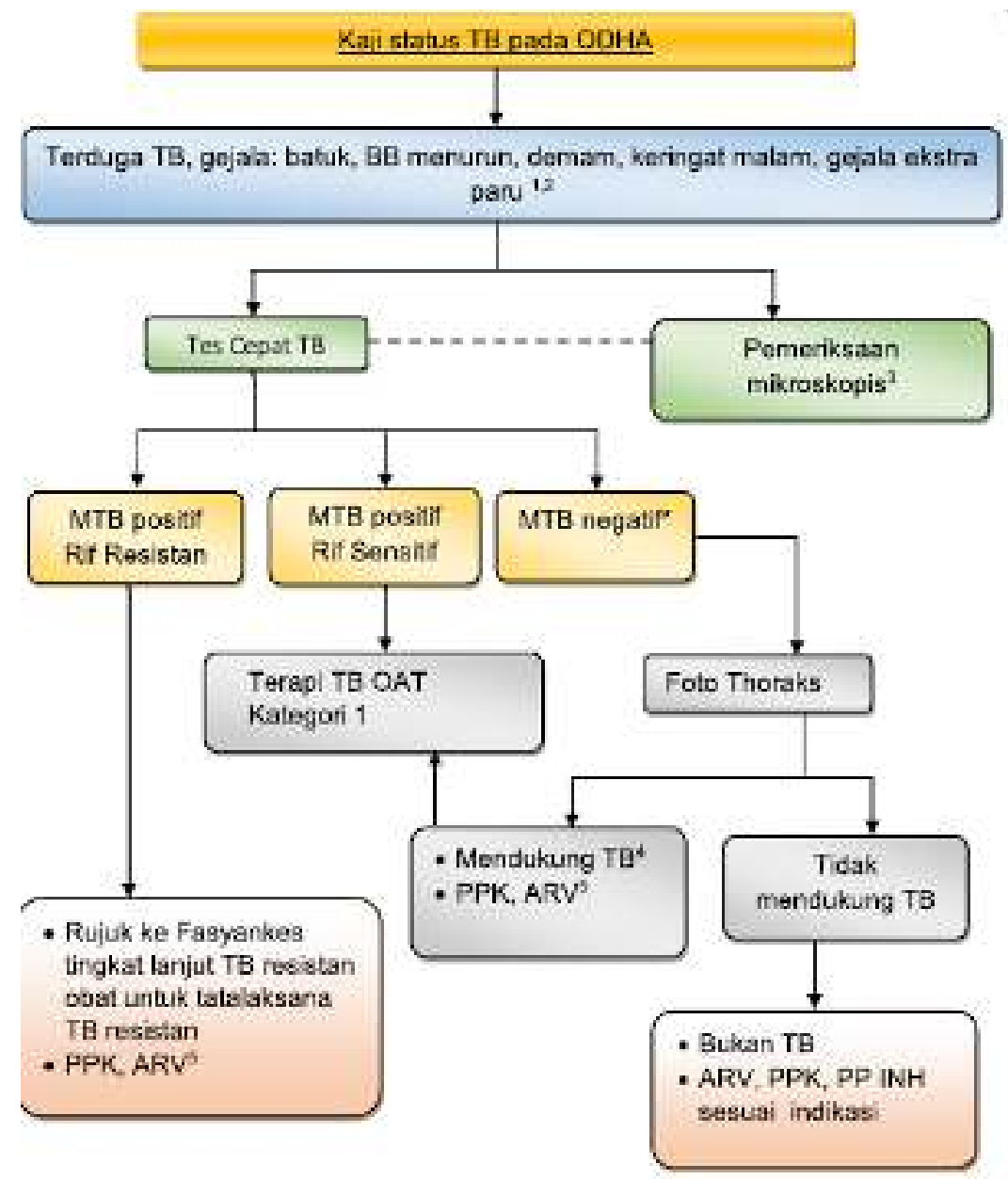

Gambar 3. Alur diagnosis TB pada ODHA (FK UNS, 2017) 
Ada beberapa hal yang harus diperhatikan pada alur pemeriksaan alur diagnosis TB paru pada ODHA, antara lain: Pemeriksaan mikroskopis langsung: pemeriksaan ini dapat dilakuan dengan uji dahak Sewaktu Pagi Sewaktu (SPS). Jika salah satu dari pemeriksaan ini menunjukkan hasil posttif, maka dapat dinyatakan sebagai pasien TB paru; Pemeriksaan tes cepat molekuler: oleh karena pemeriksaan BTA sputum pada pasien ODHA sering menunjukkan hasil negatif, maka pemeriksaan cepat molekuler seperti TCM dapat membantu menegakkan diagnosis TB paru dan mengetahui adanya Mycobacterium tuberculosa yang sensitive atau resisten; Pemeriksaan biakan dahak: pemeriksaan dilakukan pada pasien yang menunjukkan Mycobacterium tuberculosis yang resisten terhadap rifampisin. Pemeriksaan ini bertujuan untuk mengetahui resistensi OAT lainnya; Pemberian antibiotik sebagai alat bantu diagnosis pada ODHA tidak direkomendasikan. Pemberian antibiotik pada alur diagnostik TB paru pada pasien ODHA sudah tidak direkomendasikan lagi. Hal tersebut akan membutuhkan waktu diagnostik lagi. Pemberian antibiotik pada pasien TB paru dengan ODHA dilakukan jika ada infeksi bakteri sekunder pada waktu bersamaan; Pemeriksaan foto toraks: pemeriksaan rontgen toraks dilakukan untuk membantu diagnostik bakteriologis. Selain pada daerah basal paru dan juga gambaran milier.

Pengendalian TB tidak akan berhasil dengan baik tanpa keberhasilan pengendalian HIV, sebaliknya TB merupakan salah satu IO yang banyak terjadi dan penyebab utama kematian pada ODHA. Kolaborasi kegiatan bagi kedua program di semua tingkat merupakan suatu keharusan agar mampu menanggulangi kedua penyakit tersebut secara efektif dan efisien. penelitian lain juga menunjukkan dimulainya pengobatan ARV dalam 2 bulan atau setelah 2 bulan pengobatan Organisasi pelaksana Kolaborasi TBHIV melibatkan semua komponen terkait TB dan HIV dimana ditandai dengan pembentukan Kelompok Kerja TB-HIV. Pengorganisasian pelaksana kegiatan kolaborasi TB-HIV dilaksanakan dengan cara pembentukan Kelompok Kerja (POKJA) TB-HIV di bawah Kementerian Kesehatan dan di bawah Dinas Kesehatan untuk tingkat provinsi dan kabupaten/kota (Kemkes RI 2016).

Tuberkulosis merupakan penyebab infeksi oportunistik yang paling sering ditemukan pada penderita HIV/AIDS. Hal ini disebabkan komplikasi TB yang sering terjadi pada penderita HIV/AIDS. Pengobatan kedua penyakit ini tentunya memiliki tantangan tersendiri. Sebagaimana diketahui pengobatan ARV dan TB paru memiliki interaksi tersendiri, khususnya obat rifampisin dengan beberapa obat ARV tertentu. Namun beberapa penelitian juga menunjukkan inisiasi ARV minimal 2 minggu setelah pemberian OAT. Selain risiko interaksi obat OAT dan ARV, hal lain yang perlu diperhatikan adalah risiko terjadinya Immune Recostitution Inflammatory Syndrome (IRIS) yang paling sering terjadi pada pemberian ARV secara dini dalam waktu 2 minggu pemberian OAT. Namun dari tingkat mortalitas, pemberian ARV pada penderita TB tidak terdapat perbedaan antara kelompok yang diberikan ARV secara dini ataupun kelompok yang diberi ARV setelah 2 bulan pemberian OAT (Naidoo et al., 2013). 


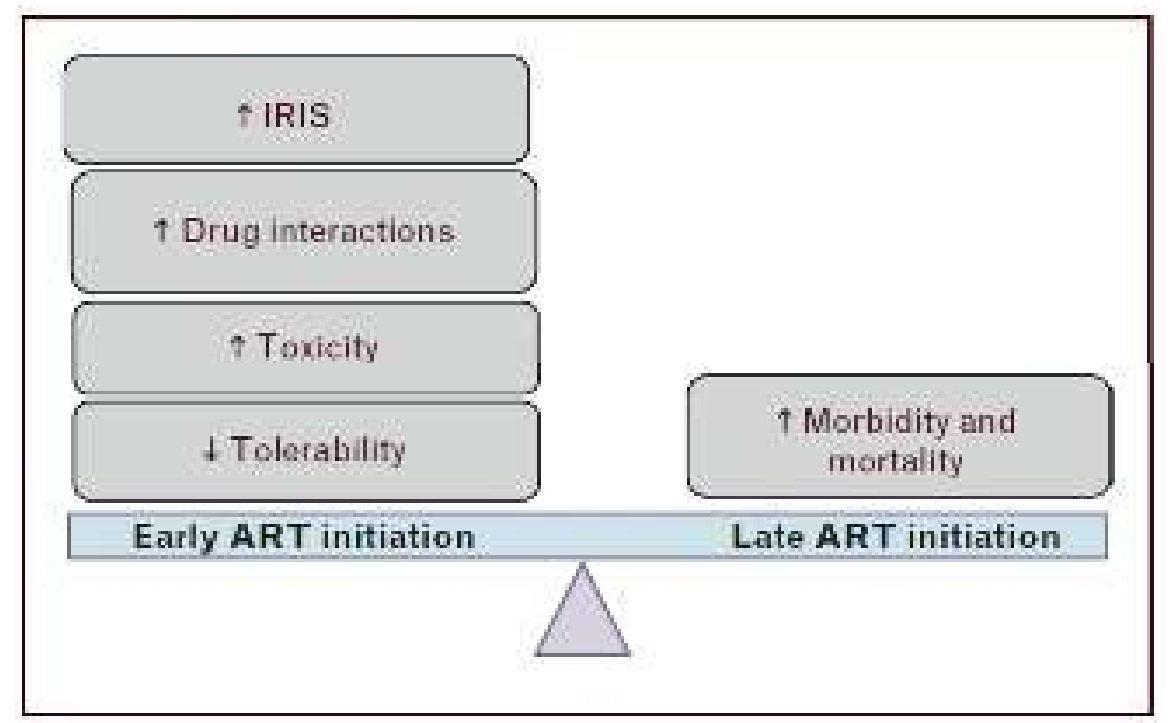

Gambar 4. Inisiasi pemberian ARV (Naidoo et al., 2013)

Selain TB paru, penyakit infeksi lainnya yang sering dijumpai pada penderita HIV/AIDS adalah Pneumocystic carinii pneumonia (PCP). Infeksi ini pada beberapa studi memiliki tingkat mortalitas mendekati 50\%. Pada pasien dengan HIV atau pasien dengan kandidiasis orofaring yang dicurigai HIV, jika terdapat keluhan demam, sesak dan/atau batuk yang tidak produktif perlu dicurigai adanya PCP. Namun gambaran klinis dapat bervariasi. Gejala PCP biasanya ringan dan memberat dalam hitungan hari hingga minggu. Namun, sekitar 7\% pasien dengan PCP tidak bergejala. Pada pasien dengan HIV / AIDS keluhan dapat berupa sesak progresif, batuk kering, dan demam yang tidak tinggi. Selain gejala, pemeriksaan fisik untuk PCP juga tidak spesifik. Pasien dapat menunjukan gejala distres pernapasan seperti takipneu, takikardia, dan sianosis. Pada auskultasi paru terdapat krepitasi saat inspirasi hingga tidak ditemukan kelainan berarti pada kasus ringan. Sedangkan, pada kasus berat dapat terjadi hipoksia (Peruzzi et al, 1992; Ismail et al., 2011).

Gambaran radiologi yang khas berupa pola infiltrat interstisial atau alveolar infiltrate. Gambaran radiologis selain pola infiltrat adalah gambaran seperti milier, sehingga diagnosis PCP dapat berupa diagnosis banding dari TB milier. Diagnosis PCP sangat sulit dilakukan karena gejala, pemeriksaan darah, serta radiografi toraks tidaklah patognomonik untuk PCP. Selain itu, Pneumocystis jirovecii tidak dapat dikultur sehingga diperlukan pemeriksaan histopatologi atau sitologi cairan dari broncho-alveolar lavage (BAL) atau sampel dari induksi sputum untuk mendiagnosis PCP secara definitif. Walaupun terdapat hambatan tersebut, deteksi kasus PCP sedini mungkin harus tetap dilakukan agar dapat segera ditangani dan mencegah mortalitas (Peruzzi et al, 1992; Ismail et al., 2011). Pemeriksaan CT scan lebih sensitif dibandingkan rontgen toraks dalam mendeteksi PCP. Pada pemeriksaan CT scan toraks akan ditemukan gambaran ground-glass appearance (crazy paving) dengan distribusi yang tidak merata. Ground-glass appearance tersebut lebih dominan di daerah perihiler. Pada keadaan yang lebih lanjut, akan ditemukan septal lines dengan atau tanpa intralobular lines superimposed pada ground-glass appearance serta konsolidasi 
(Dockrell et al., 2011). Trimetroprimsulfametoksazole (TMX-SMX) oral atau intravena selama 21 hari merupakan obat pilihan untuk menatalaksana PCP dengan atau tanpa HIV. Pada PCP derajat sedang-berat $\left(\mathrm{PaO}_{2}<70 \mathrm{mmh}\right)$ direkomendasikan trimetroprimsulfametoksazole intra-vena. Sedangkan, trimetroprimsulfametoksazole oral diberikan untuk PCP derajat ringan-sedang $\left(\mathrm{PaO}_{2} \geq 70 \mathrm{mmHg}\right)$. Rekomendasi dosis untuk terapi PCP adalah $15-20 \mathrm{mg} / \mathrm{kg}$ trimetroprim per hari dan $75-100 \mathrm{mg} / \mathrm{kg}$ sulfametoksazole per hari yang terbagi menjadi tiga atau empat dosis. Pada pasien PCP dengan HIV, respon terapi biasanya muncul lebih lama namun harus terjadi dalam delapan hari pertama. Apabila hal tersebut tidak terjadi, maka perlu dicari diagnosis alternatif atau regimen alternatif. Pada PCP derajat berat direkomendasikan untuk memberikan kortikosteroid sistemik dalam 72 jam pertama memulai terapi PCP.

Kortikosteroid sistemik perlu diberikan jika $\mathrm{PaO}_{2}<70 \mathrm{mmhg}$ atau gradien oksigen alveolar-arteri lebih dari $35 \mathrm{mmHg}$. Dosis kortikosteroid yang diberikan adalah prednisolone $40 \mathrm{mg}$ dua kali sehari per oral pada hari ke 1-5 kemudian 40mg satu kali sehari pada hari ke 6-10. Dilanjutkan dengan prednisolone $20 \mathrm{mg}$ satu kali sehari pada hari ke 11 hingga 21 (Dockrell et al., 2011; Huang et al., 2011). Pada pasien yang sebelumnya telah mendapatkan profilaksis TMX-SMX atau gagal terapi atau alergi dengan TMX-SMX, terdapat beberapa pilihan tatalaksana alternatif. Untuk PCP berat, alternatifnya adalah dapat diberikan clindamisin $600 \mathrm{mg}$ empat kali per hari, intravena atau oral dan primakuin $15 \mathrm{mg}$ satu kali per hari, oral atau pentamidine $3-4 \mathrm{mg} / \mathrm{kg}$ satu kali per hari, intravena untuk 21 hari. Sedangkan untuk PCP ringan-sedang dapat diberikan TMX 20mg/kg/hari dalam dosis terbagi tiga atau empat, oral dan dapsone 100mg satu kali per hari, oral selama 21 hari atau atorvaquone cairan suspensi 750mg dua kali per hari, oral selama 21 hari. Beratnya infeksi dan tingginya angka mortalitas pada PCP menjadikan pencegahan sangat penting dilakukan pada kelompok yang berisiko.

Trimetroprim-sulfametoksazole

juga merupakan pilihan utama profilaksis primer dan sekunder selain dapsone, atovaquone dan pentamidine. Pasien HIV harus menerima kemoprofilaksis PCP jika CD4 kurang dari $200 \mathrm{sel} / \mu \mathrm{l}$ atau terdapat riwayat candidiasis orofaringeal. Kemoprofilaksis direkomendasikan diberikan seumur hidup namun pemberiannya dapat dihentikan pada pasien yang telah mendapat ARV dan CD4nya meningkat dari $<200 \mathrm{sel} / \mu \mathrm{l}$ menjadi $>200 \mathrm{sel} / \mu \mathrm{l}$ selama 3 bulan dan dilanjutkan kembali bila CD4 kembali <200 sel/ $\mu$ l. Terdapat dua pendapat mengenai dosis profilaksis TMXSMX untuk PCP yaitu 1x960mg per oral dan 1x480mg per oral. Menurut penelitian, kedua dosis tersebut memiliki efektivitas yang sama namun semakin besar dosis yang digunakan efek samping akan semakin kuat. Selain itu, terdapat data bahwa profilaksis dengan regimenTMX-SMX 960mg tiga kali per minggu sama efektifnya jika dibandingkan dengan pentamidine nebulizer atau dapsone dan pirimetamin profilaksis namun kurang efektif jika dibandingkan dengan TMX-SMX 1x960mg (Dockrell et al., 2011; Huang et al., 2011; Kanne et al., 2012; Venkatesan, 2017). 
Tabel 1. Protokol desensitisasi trimetroprim-sulfametoksazole (Dockrell et al., 2011)

\begin{tabular}{|c|c|}
\hline Langkah & Dosis \\
\hline Hari 1 & $\begin{array}{l}80 \mathrm{mg} \text { sulfametoksazole }+16 \mathrm{mg} \text { trimetroprim } \\
\qquad\left(2 \mathrm{ml} \text { oral suspensi }{ }^{*}\right)\end{array}$ \\
\hline Hari 2 & $\begin{array}{l}1600 \mathrm{mg} \text { sulfametoksazole }+32 \mathrm{mg} \text { trimetroprim } \\
\qquad(4 \mathrm{ml} \text { oral suspensi*) }\end{array}$ \\
\hline Hari 3 & $\begin{array}{l}240 \mathrm{mg} \text { sulfametoksazole }+48 \mathrm{mg} \text { trimetroprim } \\
\left.\qquad(6 \mathrm{ml} \text { oral suspens/ })^{*}\right)\end{array}$ \\
\hline Hari 4 & $\begin{array}{l}320 \mathrm{mg} \text { sulfametoksazole }+64 \mathrm{mg} \text { trimetroprim } \\
\left(\text { ( } 8 \mathrm{ml} \text { oral suspensi }{ }^{*}\right)\end{array}$ \\
\hline Hari 5 & $400 \mathrm{mg}$ sulfametoksazole $+80 \mathrm{mg}$ trimetroprim \\
\hline $\begin{array}{l}\text { Hari } 6 \text { dan } \\
\text { seterusnya }\end{array}$ & $800 \mathrm{mg}$ sulfametoksazole $+160 \mathrm{mg}$ trimetroprim \\
\hline
\end{tabular}

Drug-induced hepatitis adalah kerusakan hati yang berkaitan dengan gangguan fungsi hati yang disebabkan oleh terpajan obat. The Food and Drug Administration (FDA) dan The Center for Biologics Evaluation and Research (CBER) mendefinisikan drug-induced hepatitis sebagai kerusakan hati yang ditandai dengan peningkatan level alanin aminotransferase (ALT/SGPT) lebih dari tiga kali batas atas nilai normal dan peningkatan level alkali fosfatase (ALP) lebih dari dua kali dari batas atas nilai normal atau peningkatan level bilirubin total lebih dari dua kali dari batas atas nilai normal jika berkaitan dengan peningkatan alanin aminotransferase atau alkali fosfatase (Jong et al., 2013).

Pemberian terapi OAT pada pasien TB dengan HIV perlu mendapat perhatian khusus karena selain OAT sendiri dapat menimbulkan druginduced hepatitis, pemberian OAT dengan ARV harus dilakukan secara benar dan hati-hati agar tidak timbul efek samping obat yang berbahaya pada pasien. Pada pola pengobatan yang holistik tersebut diharapkan pasien dapat menyelesaikan pengobatan dengan tuntas (Menezes, 2016).
Regimen anti TB berbasis rifampisin dan regimen antiretroviral berbasis efavirenz merupakan terapi lini pertama untuk pasien koinfeksi TB/HIV. Penggunaan bersama kedua regimen ini menyebabkan high pill burden, peningkatan risiko interaksi obat, dan efek samping yang tumpang tindih. Penelitian sebelumnya membandingkan kejadian efek samping obat antara pasien TB dengan/tanpa koinfeksi HIV. Diperoleh kejadian efek samping obat yang serius lebih umum ditemukan pada pasien koinfeksi TB/HIV dengan efek samping utama yang ditemukan ialah neuropati perifer dan muntah persisten (Padmapriyadarsini et al., 2011; Regazzi et al., 2014; Breen et al., 2006).

\section{KESIMPULAN}

Prosedur penegakan diagnosis pada pasien TB koinfeksi HIV/AIDS pada dasarnya tidak berbeda dengan pasien tanpa infeksi HIV/AIDS. Perlu adanya perhatian pada faktor risiko penularan HIV/AIDS untuk mengetahui penyebab dan mengetahui adanya kemungkinan infeksi lainnya. 
Pemeriksaan Tes Cepat Molekuler (TCM) sangat diperlukan pada kasus pasien ini karena seperti yang diketahui bahwa HIV/AIDS merupakan salah satu kriteria risiko untuk terjadinya TB MDR. Sedangkan tatalaksana TB koinfeksi HIV/AIDS pada prinsipnya tidak berbeda dengan pasien tanpa HIV/AIDS. Pemberian ARV diberikan minimal 2 minggu setelah OAT diberikan, walaupun beberapa literatur lain menyatakan waktu pemberian ARV yang lebih cepat lagi.

\section{KEPUSTAKAAN}

Breen RAM, Miller RF, Gorsuch T, Smith CJ, Schwenk A, Holmes W, et al., 2006. Adverse Events and Treatment Interuption in Tuberculosis Patients With and Without HIV Coinfection. Thorax, 61:791-794World Health Organization 2016. Global Tuberculosis Report 2016. Geneva: WHO Press.

Budi IS, Ardillah Y, Sari IP, Septiawati D 2018. Analisis Faktor Risiko Kejadian Penyakit Tuberkulosis Bagi Masyarakat Daerah Kumuh Kota Palembang. Jurnal Kesehatan Lingkungan Indonesia, 17(2):87-94.

Departemen Kesehatan RI 2005. Pharmaceutical Care Untuk Penyakit Tuberkulosis. Jakarta: Direktorat Bina Farmasi Komunitas dan Klinik Direktorat Jenderal Bina Kefarmasian dan Alat Kesehatan Departemen Kesehatan RI.

Dockrell DH, Breen R, Lipman M, Miller RF 2011. Pulmonary opportunistic infections. HIV Med 12(Suppl 2):25-42.

Fakultas Kedokteran UNS 2017. Tatalaksana Infeksi Tuberkulosis Laten. Departemen Pulmonologi dan Kedokteran Respirasi FK UNS Surakarta.

Huang L, Cattamanchi A, Davis JL, Boon S, Kovacs J, Meshnick S, et al., 2011. HIVassociated pneumocystis pneumonia. Proc Am Thorac Soc 8:294-300.
Ismail T, Lee C 2011. HIV associated opportunistic penumonias. Med J Malaysia 66(1):76-81.

Jong E, Conradie F, Berhanu R, Black A, John MA, Meintjes G, Menezes C, et al., 2013. Consensus statement: Management of drug-induced liver injury in HIV-positive patients treated for TB. S Afr J HIV Med, 14(3):113-119.

Kanne JP, Yandow DR, Meyer CA 2012. Pneumocystis jirovecii pneumonia: high-resolution CT findings in patients with and without HIV infection. AJR Am J Roentgenol 198(6):555-561.

Kementerian Kesehatan RI 2014. Pedoman Nasional Pengendalian Tuberkulosis. Jakarta: Direktorat Jenderal Pengendalian Penyakit dan Penyehatan Lingkungan, Kementerian Kesehatan Republik Indonesia.

Kementerian Kesehatan RI 2018. Profil Kesehatan Indonesia Tahun 2017. Jakarta: Pusat Data dan Informasi Kementerian Kesehatan RI.

Kementerian Kesehatan RI 2012. Petunjuk Teknis Tata Laksana Klinis Koinfeksi TB-HIV. Jakarta: Direktorat Jenderal Pengendalian Penyakit dan Penyehatan Lingkungan.

Kementerian Kesehatan RI 2015. Panduan Pelaksanaan Program Kolaborasi TBHIV. Jakarta: Direktorat Jenderal Pengendalian Penyakit dan Penyehatan Lingkungan.

Kementerian Kesehatan RI 2016. Petunjuk Teknis Program Pengendalian HIV AIDS dan PIMS.

Menezes C. An approach to the management of drug induced liver injury in HIV-infected patients treated for TB. Department of Internal Medicine Chris Hani Baragwanath Academic Hospital, University of The Witwatersrand. [cited April 10, 2016]

Naidoo K, Baxter C, Abdool Karim SS 2013. When to start antiretroviral therapy during tuberculosis treatment? Curr Opin Infect Dis. 26(1):35-42.

Padmapriyadarsini C, Narendran G, Swaminathan S 2011. Diagnosis \& Treatment of Tuberculosis in HIV Co- 
infected Patients. Indian J Med Res, 134(6):850-865.

Peruzzi WT, Shapiro BA, Noskin GA, Currie

DL, Skoutelis A, Murphy RL, et al., 1992.

Concurrent bacterial lung infection in patients with AIDS, PCP, and respiratory failure. Chest 101(5):1399_ 1403.

Regazzi M, Carvalho AC, Villani P, Matteelli A 2014. Treatment Optimization in Patients CoInfected with HIV and Mycobacterium tuberculosis Infections: Focus on DrugDrug Interactions with Rifamycins. Clin Pharmacokinet, 53(6):489-507.

Venkatesan P 2017. Guideline for the treatment of Pneumocystis jirovecii pneumonia (PCP) in adults. Inggris: Nottingham University Hospital.

World Health Organization 2015. Global Tuberculosis Report 2015. Geneva: WHO Press. 